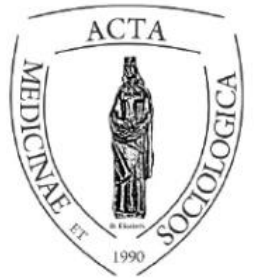

Acta Medicinae et Sociologica (2021)

Vol. 12. No. 32. (24-49)

UNIVERSITY OF

DEBRECEN

doi:

FACULTY OF

HEALTH

https://doi.org/10.19055/ams.2021.05/31/2

NYÍREGYHÁZA

\title{
Az egészség komplex megközelítése, mint az egészség- szociológiai vizsgálatok elméleti kerete
}

\author{
Moravcsik-Kornyicki Ágota ${ }^{1}$, R. Fedor Anita ${ }^{2}$ \\ ${ }^{1}$ Szabolcs-Szatmár-Bereg Megyei Kórházak és Egyetemi Oktatókórház- Egészségfejlesztési \\ Osztály, osztályvezető. Pécsi Tudományegyetem Egészségtudományi Doktori Iskola, PhD. \\ hallgató \\ ${ }^{2}$ Debreceni Egyetem Egészségügyi Kar, Nyíregyháza, Sóstói u. 2-4., főiskolai tanár
}

\begin{tabular}{|c|c|}
\hline INFO & ABSTRACT \\
\hline $\begin{array}{l}\text { Kapcsolattartó szerző } \\
\text { neve } \\
\text { Moravcsik-Kornyicki } \\
\text { Ágota korago- } \\
\text { ta@gmail.com } \\
\text { Keywords } \\
\text { health definition, determi- } \\
\text { nants, complex models, } \\
\text { holistic approach, health } \\
\text { inequality }\end{array}$ & $\begin{array}{l}\text { Abstract The health indicators of the population are worst in } \\
\text { the whole Central and Eastern European region, and thus in } \\
\text { Hungary as well. The health status of Hungarians is not possi- } \\
\text { ble, it is not a unique phenomenon. The state of health of the } \\
\text { Hungarian society is one of the worst in the European Union. } \\
\text { To advance the understanding of the situation, it is necessary } \\
\text { to conduct complex interdisciplinary studies that combine } \\
\text { health and social science models. } \\
\text { In our study, we present a complex approach to health, its } \\
\text { social embeddedness, with the aim of providing a theoretical } \\
\text { basis for a study we have designed to target Hungarian health } \\
\text { characteristics. } \\
\text { The theoretical overview emphasizes the context of the } \\
\text { definition of health used in certain disciplines of the social } \\
\text { sciences, the presentation of the explanatory factors of health, } \\
\text { and the theses and models. Outlining our present work and } \\
\text { future research cannot be without tracking the changes that } \\
\text { have taken place that determine health, so we will first analyze } \\
\text { this. In laying the theoretical foundations, we return to the } \\
\text { complex approach to health, in which we present the presenta- } \\
\text { tion of biomedical and bio-psycho-social models in detail, and } \\
\text { then we describe the economic and social models of health. } \\
\text { We also deal with health determinants that determine the } \\
\text { health of the individual and society. }\end{array}$ \\
\hline
\end{tabular}




\section{Kulcsszavak}

egészség definíció, meghatározó tényezők, komplex modellek, holisztikus szemlélet, egészségegyenlötlenség

\begin{abstract}
Absztrakt A közép-kelet-európai térség egészében, és így Magyarországon is rosszak a népesség egészségmutatói. A magyarok egészségi állapota nem elszigetelt, nem egyedi jelenség. Magyarország társadalmának egészségi állapota a legrosszabbak közé sorolható Európai Uniós viszonylatban.

Tanulmányunkban az egészség komplex megközelítését, a társadalmi beágyazottságát mutatjuk be azzal a céllal, hogy elméleti alapját adjuk egy általunk tervezett a hazai egészség jellemzőket célkeresztbe állító vizsgálatnak.

Az elméleti áttekintésben hangsúly helyeződik a társadalomtudományok bizonyos tudományterületei által használt egészség definíciókra, az egészség magyarázó tényezőinek bemutatására, tézisek és modellek kontextusára. Jelen munkánk és jövőbeli kutatásunk körülírása nem nélkülözheti az egészség fogalmának meghatározásban lezajlott változások nyomon követését, ezért elsőként ennek elemzésre térünk ki. Az elméleti alapok lefektetésében az egészség komplex szemléletéhez nyúlunk vissza, melyben a biomedikális és bio-pszichoszociális modellek bemutatására térünk ki részletesen, majd az egészség gazdasági és társadalmi modelljeit ismertetjük. Továbbá foglalkozunk az egyén és a társadalom egészségét meghatározó egészségdeterminánsokkal is.
\end{abstract}

\section{Bevezetés}

Általánosan ismert, hogy a közép-kelet-európai térség egészében, - így hazánkban is - a népesedési mutatók, a demográfiai folyamatok az utóbbi évtizedekben kedvezötlenül alakultak. Az ország népessége 1981 óta folyamatosan csökken, évröl évre kevesebben születnek, mint ahányan meghalnak. A hazai korfa egy fogyó, elöregedő népességről árulkodik. Ennek oka, hogy az elmúlt 40 évben kevesebben születtek, mint ahányan meghaltak. Mindemellett jó hír, hogy jelentősen nőtt a születéskor várható átlagos élettartam, bár nemzetközi összehasonlításban továbbra is van még lemaradásunk. Magyarország társadalmának egészségi állapota a legrosszabbak közé sorolható Európai Uniós viszonylatban, különösen igaz ez a férfiakra és a sérülékeny csoportokra. Magyarországon a népességszám alakulása szorosan összefügg a magyar lakosság egészségi állapotával (Moravcsik-Kornyicki és mtsai 2017). Az Európai Bizottság által koordinált Háztartási Költségvetési és Életkörülmények Adatfelvétel (továbbiakban: HKÉF) 2015. évi mutatóit (European Union Statistics on Income and Living Conditions [továbbiakban: EU-SILC]) 
alapul véve az Európai Unió (továbbiakban: EU) tagországainak átlagához $(7,8 \%)$ képest Magyarországon kedvezőtlenebb az egészségi állapot szubjektív megítélése. Hazánkban csaknem kétszerese $(12,4 \%)$ azoknak az aránya, akik nagyon rossznak tartják egészségi állapotukat (EUROSTAT 2017). Az önminősített egészségi állapot mellett az egészségi állapot objektív jellemzöiben (születéskor várható átlagos élettartam, megbetegedései és halálozási adatok) is kedvezőtlen helyre szorul a magyar lakosság az adatai szerint, a nemzetközi mutatókhoz viszonyítva. A születéskor várható átlagos élettartam a hazai női társadalmat vizsgálva 2019-ben 79,33 év volt, míg a férfiaké 72,86 év. Férfiak esetén a 2001-es mutatószámhoz viszonyítva $+4,71$ évnyi emelkedést, míg nők esetén $+2,87$ évnyi emelkedést látunk (KSH 2021), azonban az EU hoz viszonyított számadat (EU:81 év vs. Mo:76,2 év) tekintetében még mindig jelentős elmaradás mutatkozik. A különbség az országon belül (Kelet-Nyugat) és a nemek (ffi-nő), a társadalmi-gazdasági csoportok közötti és az iskolázottságot tekintve továbbra is fennáll. 2016-ban továbbra is a keringési rendszer betegsége volt messze a legmagasabban vezető halálok, és a szív- és érrendszeri betegségekre visszavezethető elhalálozások sokkal gyakoribbak voltak Magyarországon, mint a legtöbb uniós országban. Noha az ischaemiás szívbetegségből eredő halálozás az egész EU-ban több mint 40\%-kal esett vissza 2000 és 2016 között, ez a csökkenés jóval mérsékeltebb volt Magyarországon, ahol a mortalitás mindössze 12\%-kal lett alacsonyabb. Az agyi érkatasztrófával összefüggő halálozás gyorsabb ütemben csökkent ugyanezen időszakban, de így is lényegesen meghaladja az uniós átlagot. Szembetűnő vonás, hogy Magyarországon volt a legmagasabb a rák okozta mortalitás 2016-ban; a rákkal összefüggő halálozások leggyakoribb okai pedig a tüdőrák, a vastagbélrák, a májdaganat és az emlőrák voltak, ami részben a szürési és népegészségügyi programokba történő invesztálás alacsony fokáról tanúskodik (OECD 2019).

Az ok keresésénél a genetikai eredetű megbetegedések mellett egyre nagyobb figyelem vetül azokra a társadalmi folyamatokra és társadalmi háttérváltozókra, amelyek nagymértékben befolyásolják az egyének egészségi állapotát. Mindez azt támasztja alá, hogy foglalkozni kell a magyar társadalom egészségi állapotának multidiszciplináris megközelítésen alapuló vizsgálatával. Időszerüek azok az empirikus munkák, melyek az egyes társadalmi és demográfiai csoportok speciális élethelyzetéből, életmódjából, lakóhelyéből adódó hátrányokkal összefüggő egészségegyenlőtlenségekhez vezetnek. 
Tanulmányunkban az egészség komplex megközelítésének a lehetöségét, társadalmi beágyazottságát mutatjuk be, azzal a céllal, hogy elméleti alapját adjuk egy általunk tervezett a hazai egészség jellemzőket célkeresztbe állító vizsgálatnak.

\section{Az egészség meghatározása, fogalmának értelmezése}

Az egészség fogalmának meghatározása és értelmezése nem könnyü feladat, mert ahány ember él a világban annyi féle elképzelés, priorizálás létezik az egészség megfogalmazását célozva, hiszen az egészségről alkotott véleményt számos egyéni tényező befolyásolja. Az egészség fogalma változó, fejlődő fogalom, ezért nem meglepő, hogy az idők során számos kísérlet született az egészég megfogalmazására és definiálására melyek magas számban fellelhetőek a szakirodalomban (Székely, Simon, Vergeer 2007).

$\mathrm{Az}$ archaikus időszakban a betegséget, a fájdalmat valamilyen természetfeletti jelenségnek tulajdonították, ezért a gyógyítást és a gyógyulást is a szellemvilágtól várták (Kapitány Á., Kapitány G. 2014). A testben zajló folyamatokról az akkori orvoslás fejlettsége még nem állt kész evidencia alapú orvoslással (evidence based medicine, továbbiakban: EBM) nyilatkozni, ezért a társadalom tagjai gyógyulást remélve papokhoz, varázslókhoz, kuruzslókhoz fordultak és a misztikumban vagy a vallásban keresték a megoldást.

A XIX. századi ipari társadalmakban az egészség fogalma az orvostudomány és a gazdaság fejlődésének hatására új jelentést kapott. Az árutermelés megindulása után más vélemények születtek. A gazdasági fejlődés, stagnálás és zsugorodás szignifikánsan meghatározza a társadalmi életviszonyokat, ezen belül is az egészségi állapotot vallotta Karl Marx (1818-1883), akit a szociológia alapító atyjai között tartunk számon. Helbert Spencer (18201903) korabeli szociológus-biológus szerint az egészség az, amikor a szervezet tökéletesen alkalmazkodik a környezetéhez.

Az orvostudomány gyors ütemü fejlödése lehetővé tette, hogy korábban gyógyíthatatlannak tünő és vélt betegségekböl az adott egyén meggyógyult. Ez azt a perspektívát erősítette az orvostudományban, hogy a betegek döntő többségét valamilyen orvosi beavatkozással, vagy gyógyszerkészítmények adásával meg lehet gyógyítani. A hagyományos megközelítés szerint a medikális szemléletet követve az egészség a betegség hiányát jelenti, azaz az számít egészségesnek, aki nem beteg. Ezt követően vált elterjedtté a biomedikális szemlélet az orvostudományban. A felfogást/modellt képviselő szakembe- 
rek az adott egyén környezeti faktorjait tették elsősorban felelőssé a betegségek kialakulásában, a terápia pedig az orvostudományból származott, a társadalmi hatásokat egyáltalán, vagy szinte alig gondolták befolyásolónak.

Az egészséget össztársadalmi szinten elfogadott módon, első ízben az Egészségügyi Világszervezet (továbbiakban: EVSZ, World Health Organization, azaz WHO) 1946-ban történő megalakulásakor definiálta az alábbiak szerint: „Health is a state of complete physical, mental and social well-being and not merely the absence of disease or infirmity" (EVSZ 2006) [magyar fordítás: Az egészség a teljes testi, lelki és szociális jól-lét állapota, és nem csupán a betegség vagy fogyatékosság hiánya].

A fogalom megalkotása gondolkodásmód változást hozott, hiszen tartalmazta annak az addig követett hagyományos szemléletnek a paradigma váltását, mely szerint az egészséghez betegség-központú megfogalmazásban közelítsünk. Az egészség nem csupán a betegség hiányát jelenti, annál többről van szó, a fogalom kihangsúlyozza, hogy az egészséghez szükség van a testi egészségen túl a mentális és társadalmi jóllétre is, de még inkább arra, hogy ez a hármas, teljességgel jelen legyen az adott egyénnél. Az egészség fogalmának megalkotásakor azonban joggal tehetjük fel a kérdést, mely szerint leírható-e az egészség egymondatos fogalomkörben, ugyanis a meghatározói számos területről érintettek (Wylie 1970). Az alapvető hármas (testi, lelki, szociális) teljességének megbomlása már az egészség elvesztését jelentené? A fogalom, szó szerinti értelmezésénél a válasz: igen. Azonban azt is látnunk kell, hogy gyakran billen ki valamelyik pillérünk, mégsem valljuk magunkat egészségtelennek. Ebben a gondolkodásmódban joggal mondhatjuk, hogy a több, mint 70 éve megalkotott egészség definíció nem realisztikus. A szakmai grémium azonban a mai napig előszeretettel használja ezt a megközelítést az egészség fogalmának meghatározásakor.

Napjainkban is elfogadott Joseph Stokes és mtársai (1982) által megfogalmazott egészség meghatározás mely szerint: anatómiai integritással jellemzett állapot; személyes teljesítőképesség és alkalmasság különböző szerepek betöltésére a családban, a munkahelyen és a társadalomban egyaránt; fizikai, -biológiai képesség a társadalmi stressz kezelésére; jó közérzet továbbá mentesség a megbetegedés és az idő előtti halálozás fenyegetésétől (Stokes, Noren, Shindell 1982).

Ugyanezt a szemléletet tükrözi Talcott Parsons 1948-ban közel 40 évvel korábbi egyészség definíciója, mely kimondja, hogy az egészség az egyén optimális teljesítőképességének állapotát jelenti, ezáltal azoknak a szerepek- 
nek és feladatoknak a betöltésére teszi képessé, melyekre szocializálódott. Az egészség akkor adott, ha az egyén szociálisan integrálódott, a változó terhelésekhez alkalmazkodni tud, individuális önállóságát megőrzi, megteremti az összhangot a biogenetikai, a fizikai, a pszichológiai és a szociális lehetőségei között (Parson 1948).

$\mathrm{Az}$ egészségfejlesztés alapdokumentumában, az Ottawai Chartában (1986) a megfogalmazás szerint az egészségnek vannak bizonyos alapfeltételei, úgymint béke, lakás, oktatás, élelem, jövedelem, stabil ökológiai rendszer, fenntartható erőforrások, társadalmi igazságosság és egyenlőség, amelyeket az egészség javításához biztosítani kell. A teljes fizikai, szellemi és szociális jólét állapotának elérése érdekében az egyénnek vagy csoportnak képesnek kell lennie arra, hogy megfogalmazza és megvalósítsa vágyait, kielégítse szükségleteit, és környezetével változzék vagy alkalmazkodjon ahhoz. Az egészség pozitív fogalom, amely a társadalmi és egyéni erőforrásokat, valamint a testi képességeket hangsúlyozza. Az egészséget tehát, mint a mindennapi élet erőforrását, nem pedig mint életcélt kell értelmezni (ÁEEK 2021).

David Seedhouse és mtsa 1989-es egészségmeghatározása alapján az egészség optimális állapota egyenlő azon feltételek összességével, amelyek megléte esetén az egyén kibontakoztathatja a számára adott lehetőségek öszszességét. Seedhouse az egészségre, mint képességre tekint. Az emberek valós potenciáljának eléréséhez szükséges alap, mely lehetővé teszi, hogy valóra váltsa a benne rejlő célokat (Seedhouse és Cribb 1989). Ez az újfajta megközelítés rávilágít arra, hogy egyénileg mást és mást tartsunk egészségesnek és így máshogyan gondolkozzunk az egészség fogalmáról.

A globalizáció hatására az egészség fogalmának kompetenciaköre egyre növekvő tendenciát mutatott, látszott, hogy széles spektrumú alkotóeleme jelenik meg. Megállapítást nyert, hogy az egészség a funkcionalitás megfelelönek ítélt szintje az egyén által. Az Egészségügyi Világszervezet által megalkotott és számos szakirodalomban sokszor említett és hivatkozott klasszikus fogalom a jelenleg is nagy elismerésnek örvendő hazai szakmai grémium megítélése szerint is idealisztikussá vált, hiszen a teljes tökéletes egészségi állapot a gyakorlatban igen ritkán van jelen az egyénnél. Alapvetően döntő, a saját (vélt) egészségünk meghatározásánál, hogy milyen mértékben vagyunk elégedettek a testi, lelki és szociális állapotunkkal, azaz mennyire értékeljük jónak saját funkcionális teljesítőképességünket (Ádány 2011). A reális megfogalmazás alapján ugyanakkor azt is látni kell, hogy az egészség objektíven 
sohasem határozható meg, mert az egészségröl alkotott társadalmi kép mindig szubjektív, azaz egy adott társadalom aktuális elvárásai szerint alakul. Libicki és R. Fedor (2020), valamint R. Fedor (2019) a szubjektív egészségi állapotot fókuszba állító tanulmányában pontosan arra világít rá, hogy ezek a vizsgálatok igénylik a multidiszciplináris megközelítést. Merész, de realista megközelítéssel tehát az egészség fogalma a lakosság általános egészségi állapota, valamint az orvostudomány fejlettsége alapján alakul ki figyelembe véve az egyén korát, korcsoportos besorolását egészségképről alkotott ismereteit (korcsoportonként változó), így egészséges az, akinek az egészségi állapota nem rosszabb, mint az így kialakított társadalmi elvárás. Az egészség megítélése a funkciók müködésén (képességek, korlátozottságok), a fájdalom létén, jellegén, és mindennek az egyén általi mentális feldolgozásán (elfogadásán) alapul (Borbás és mtsai 2008).

Látható, hogy az egészségfelfogás, az egészségről alkotott vélemények igen szerteágazóak, jelentősen módosultak a társadalmi, gazdasági, térbeli és időbeli kontextusban. Azonban közelebbről megvizsgálva az egyes definíciók tartalmi elemeit azt látjuk, hogy az egészség definíció egy irányba mutat, vagyis, hogy az egészség megítélésében nem nélkülözhetőek azok a társadalmi, gazdasági, kulturális és tudományos szempontok, amelyek együttesen alakítják az egészségről való gondolkodást, és amelyben ugyanúgy megjelennek az objektív, mint a szubjektív szempontok. Ezt illusztrálja a 1. számú táblázat. 
1. számú táblázat: Az egészségről való gondolkodás fogalmi értelmezése és változása

\begin{tabular}{|c|c|}
\hline $\begin{array}{l}\text { EGÉSZSÉG DEFINÍCIÓT } \\
\text { ALAKÍTÓ KORSZA- } \\
\text { KOK/SZAKEMBEREK/ } \\
\text { SZERVEZETEK/; ÉVSZÁMOK }\end{array}$ & $\begin{array}{l}\text { EGÉSZSÉG FOGALMI ÉRTELME- } \\
\text { ZÉSE ÉS VÁLTOZÁSA }\end{array}$ \\
\hline $\begin{array}{c}\text { archaikus időszak } \\
\text { (Kr. e. 7. sz. végétől 480-ig) }\end{array}$ & $\begin{array}{l}\text { a betegség, a fájdalom valamilyen termé- } \\
\text { szetfeletti jelenség }\end{array}$ \\
\hline $\begin{array}{l}\text { Karl Marx } \\
(1818-1883)\end{array}$ & $\begin{array}{c}\text { a gazdasági fejlődés, stagnálás és zsugoro- } \\
\text { dás meghatározza a társadalmi életviszo- } \\
\text { nyokat }\end{array}$ \\
\hline $\begin{array}{l}\text { Herbert Spencer } \\
(1820-1903)\end{array}$ & $\begin{array}{l}\text { az egészség rugalmasság, a szervezet töké- } \\
\text { letes alkalmazkodása a környezetéhez }\end{array}$ \\
\hline $\begin{array}{l}\text { World Health Organization-WHO } \\
\qquad(1946)\end{array}$ & $\begin{array}{c}\text { az egészség a teljes testi, lelki és szociális } \\
\text { jóllét állapota, és nem csupán a betegség } \\
\text { vagy fogyatékosság hiánya }\end{array}$ \\
\hline $\begin{array}{l}\text { Talcott Parsons } \\
\text { (1948) }\end{array}$ & $\begin{array}{l}\text { az egészség az egyén optimális teljesítőké- } \\
\text { pességének állapotát jelenti }\end{array}$ \\
\hline $\begin{array}{l}\text { Joseph Stokes (III.) és mtsi. } \\
\qquad(1982)\end{array}$ & $\begin{array}{l}\text { az egészség anatómiai integritással jellem- } \\
\text { zett állapot, képesség és alkalmasság éle- } \\
\text { tünk során különböző szerepek betöltésére, } \\
\text { jó közérzet, továbbá } \\
\text { mentesség a megbetegedés és az idő elötti } \\
\text { halálozás fenyegetésétől }\end{array}$ \\
\hline $\begin{array}{l}\text { Ottawai Charta } \\
\text { (1986) }\end{array}$ & $\begin{array}{l}\text { az egészség a mindennapi élet erőforrása, } \\
\text { nem életcélként tekinthető }\end{array}$ \\
\hline $\begin{array}{l}\text { David Seedhouse } \\
\text { (1989) }\end{array}$ & $\begin{array}{l}\text { azon feltételek összességével, amelyek } \\
\text { megléte esetén az egyén kibontakoztathatja } \\
\text { a számára adott lehetőségek összességét }\end{array}$ \\
\hline $\begin{array}{l}\text { Borbás Ilona és mtsi. } \\
\text { (2008) }\end{array}$ & $\begin{array}{l}\text { a társadalom aktuális elvárásai alapján } \\
\text { határozható meg }\end{array}$ \\
\hline $\begin{array}{l}\text { Ádány Róza } \\
\text { (2011) }\end{array}$ & $\begin{array}{l}\text { az egészség a vélt egészségünk tükrözödé- } \\
\text { se }\end{array}$ \\
\hline
\end{tabular}

Forrás: (saját szerkesztés) 


\section{Az egyén és társadalom egészségét meghatározó tényezők, egészségde- terminánsok}

Egészségdeterminánsok alatt azokat az alapvető tényezőket és hatásokat értjük, melyek az egyén és tágabb értelmezésben egy közösség, egészségi állapotát meghatározzák, befolyásolják.

\section{Az egészség egyéni meghatározói}

Marc Lalonde kanadai egészségügyi és népjóléti miniszter 1974-ben közreadott egy kiadványt (Lalonde riport), mely összegezte, hogy a környezet (strukturális megközelítés) és az emberi magatartás (életmód megközelítés) jobbítása, a megbetegedés és idő előtti halálozás jelentős csökkenését eredményezné (Lalonde 1974). Ezen egészséget meghatározó tényezőket az adott egyén szempontjából vizsgálva Marc Lalonde négy fö csoportba sorolta életmód, genetika, környezet, egészségügyi ellátórendszer - melyek különböző arányban járulnak hozzá az egészség alakításához és fenntartásához. A négy kategóriából McGinnis a különböző tényezők arányát a következőképpen adta meg 2002-ben: életmód 40\% (étkezési szokások, fizikai aktivitás, dohányzás, alkoholfogyasztás), genetika, biológiai faktorok 30\% (életkor, nem, genetikai adottság, fogékonyság), környezeti tényezők 5\% (lakáskörülmények, levegőszennyezettség, foglalkozási ártalmak), társadalmi - gazdasági tényezők 15\%, egész-ségügyi ellátás $10 \%$ (Mc Ginnis, Williams-Russo. Knickman 2002). Más szakemberek vélelme szerint az életmódbeli tényezők 43\%-ban (30-60\%), a genetikai tényezők 27\%-ban (15-30\%) a környezeti tényezők 19\%-ban (15-25\%) és az egészségügyi ellátórendszer és az ellátás (mennyiségi és minőségi mutatói) csupán 11\%-ban (10-15\%) határozza meg az adott egyén aktuális egészségi állapotát (1. sz. ábra). Az egészség meghatározásában a különböző egészséget befolyásoló tényezők (egészségdetermináns csoportok) súlya tehát nem azonos. A jó egészség elsősorban nem az egészségügyi ellátórendszer milyenségén (felszerelés, szakembergárda, elérhető szolgáltatás) vagy az orvoson (felkészültség, tudás) múlik. Egészségi állapotunkat elsődlegesen mindennapi döntéseink (életmód), közvetlen környezetünk, a család, az iskola, a munkahely, a lakóhely, valamint a genetikai állományunk határozza meg. Ezek az arányszámok az egyes országokat vizsgálva, eltérően alakulhatnak, így természetesen Magyarországon is. 
1. számú ábra: Az egyéni egészségi állapotot meghatározó tényezők csoportjai és megoszlásuk (\%), (Lalonde Riport, 1974.)

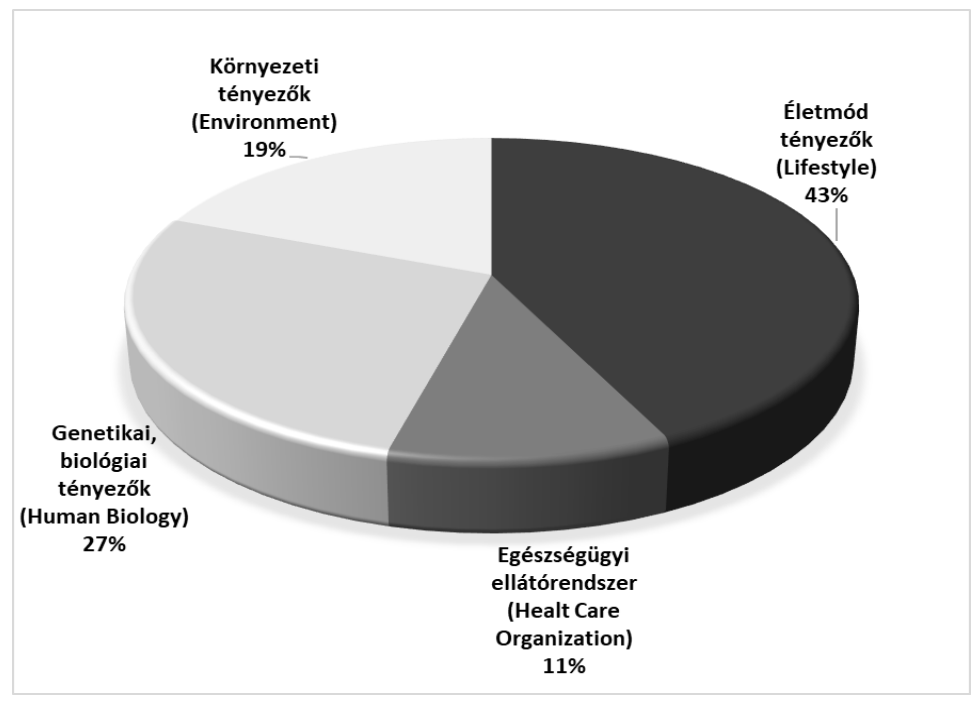

Forrás: (saját szerkesztés)

Az egészségi állapot alakításához hozzájáruló százalékos megoszlásokat tekintve az országok között lehetnek eltérések, azonban kétség kívüli tény, hogy a megoszlások alapján vett sorrendiségüket tekintve megegyezőek az eredmények. Kiemelt szerep jut az arányelosztás tekintetében az életmód tényezőknek, mely esetén evidencia, hogy társadalmilag, gazdaságilag és kulturálisan meghatározottak. Az egészséget jelentősen befolyásolja a szociális státusz, amely az anyagi helyzetnek és a társadalmi kapcsolatoknak köszönhetően a társadalmi erőforrásokhoz való hozzáférést határozza meg (Vitrai és Mihalicza 2006).

Az egyéni egészségi állapotot meghatározó csoportok részletezése:

- az életmód tényezők csoportját képezi a mindennapi rutin részévé vált negatív és pozitív hatással bíró cselekedeteink sora (pl.: az étkezési szokásaink, a fizikai aktivitás megléte vagy épp hiánya, magatartási tényezők, a rizikómagatartások megléte [dohányzás, alkoholfogyasztás]);

- a genetika, biológiai faktorok csoportja nem befolyásolhatók az egyén által, de az életmódbeli tényezők erösíthetik vagy gyengíthetik a hajlam és kockázati tényezők megjelenését a különböző betegségek kialakulása kapcsán (pl.: életkor, nem, genetikai adottság, fogékonyság különböző betegségek kialakulására a szervezetben, egészséges fejlődés); 
- a környezeti tényezők csoportja szintén meghatározott és korlátozott a ráhatási lehetősége az egyént tekintve, az viszont minden szakmai állásfoglalás szerint is elfogadott, hogy két részre osztható, szükebb és tágabb környezetre. A szükebb környezeti tényezök befolyásolása elérhető az egyén által (pl.: iskolázottság, társas kapcsolat), de a tágabb környezeti tényezők a genetikai meghatározókhoz hasonlóan kevésbé befolyásolhatók (pl.: éghajlat, levegőszennyezettség, foglalkozási ártalmak fennállása, kulturális sajátosságok, társadalmi támogatottság);

- az egészségügyi ellátás minősége és annak elérhetősége és fejlettsége Mc Ginnis és munkacsoportja által kialakított struktúra szerint is csupán 10\%-ban határozza meg az egészségi állapot milyenségét (McGinnis, Williams-Russo, Knickman 2002) és az egyén szempontjából szintén kevésbé befolyásolható.

Az egészségdeterminánsok ismerete nem kizárólag az egészség meghatározottságának és az egészségmodellek értelmezéséhez szükségesek, de az egészégi állapot javítását célzó intervenciók támadáspontjának meghatározásához is nélkülözhetetlen. A Lalonde riport hangsúlyozta, hogy a különböző színtéren tervezett interakció előtt meg kell vizsgálni azokat a tényezőket és azok mutatószámainak alakulását, melyek befolyásolják egy ország, közösség lakosainak és az adott egyén egészségi állapotát. Az egészségdeterminánsok kedvező befolyásolásával az egyén és a közösség egészségi állapota javítható (Ádány 2011). A Lalond riportban említett négy egészséget meghatározó terület csoportkategórián belül számos mutató, úgynevezett egészségdetermináns befolyásolja az egészégi állapotot.

\section{A közösség egészségét meghatározó tényezök}

Az egyén egészségi állapota meghatározza és hozzájárul a közössége egészségének megítéléséhez, minél egészségesebbek a közösség egyéni tagjai, annál jobb a közösség együttes egészsége. Az egyénen kívüli külső tényezők nem csak az egyénre, hanem a benne élő közösségek együttes egészségére is hat. Megjelenésük és hatásuk a társadalmi-gazdasági környezet függvényében változik. A közösség egészségét meghatározó egészségdeterminánsok csoportjait három fő kategóriába sorolhatjuk: egyéni sajátosságok, társadalmi környezet, fizikai környezet. (2. sz. ábra) 
- Az egyéni sajátosságok csoportja magában foglalja az egyén öröklött genetikai-, magatartási tényezőit és jellemzőit, a tanult készségeit és értékrendjét, de a lelki egyensúlyát is;

- A társadalmi környezet csoport, a neveltetésen át magába foglalja a családi-, baráti-, munkahelyi-, és szociális környezetet, de tartalmazza az egészségügyi ellátást és a szabadidős tevékenységet;

- A fizikai környezet csoport részét képezi a természetes és mesterséges környezeti tényezők. (2. sz. ábra)

2. számú ábra: A közösség egészségét meghatározó tényezők csoportjai

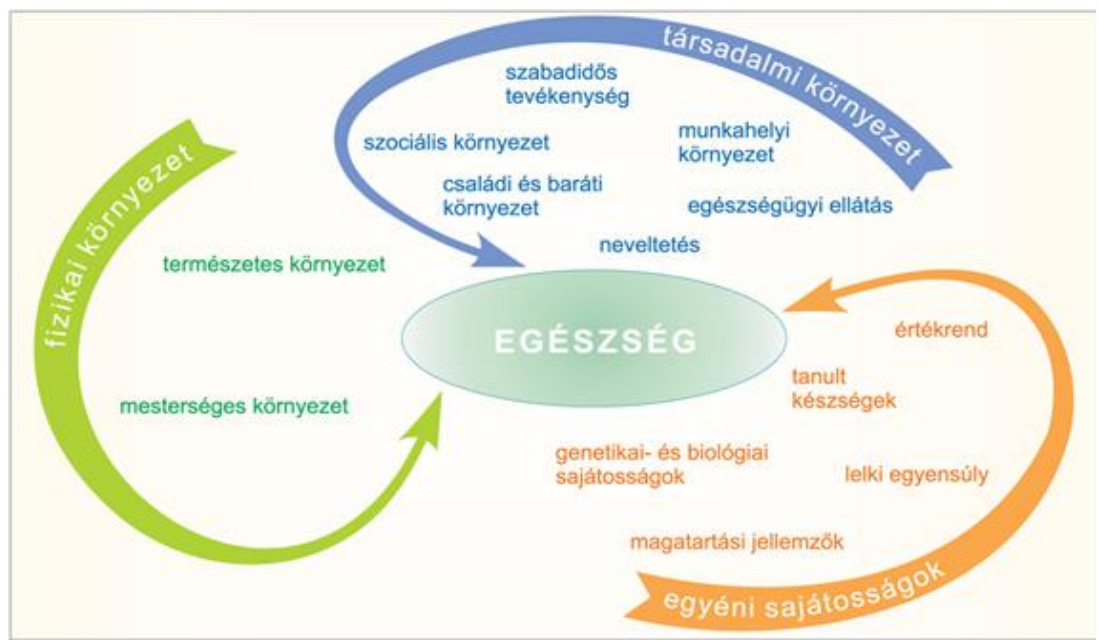

Forrás: Ádány Róza (szerk.): Megelőző orvostan és népegészségtan; Medicina Könyvkiadó Zrt., 2011.

\section{Az egészség komplex szemlélete}

Az egészség modelleket döntően három tényező határozza meg. Az első, hogy miként gondolkodik a megalkotója az egészség definíciójáról (ld. első fejezet). A második kulcstényező az egészséget meghatározó (egyéni és közösségi) tényezők, azaz az egészségdeterminánsok köre, amelyekre az egészségmodell kiterjed (ld. második fejezet). A harmadik a determinánsok között feltételezett kapcsolatrendszer és annak erössége.

\section{Az egészség biomedikális modellje}

A ma is erős hagyományokkal rendelkező gyógyító (kuratív) szemléletmód a biomedikális vagy biomedicinális modellen alapul, melynek megalkotását a 
XIX. századtól a természettudományok fejlödése erősítette meg. A modell legrészletesebb leírását D. Seedhouse alkotta meg. A modellnek számos jellemzője van, melyek az alábbiak: 1. Akkor van egészség, ha nincs betegség. 2. Az egészség árucikk. 3. Az orvostudomány a tudása birtokában az emberi szervezethez nem élölényként, hanem szerkezetként viszonyul. 4. A betegséget legjobb kezelni azzal a módszertannal, hogy a legkisebb alkotóelemére bontjuk. 5. Az egészség mérhető, mennyiségileg kifejezhető, mégpedig úgy, hogy a jellemző paramétereket populációkra, csoportokra vagy egyénekre megadott normákhoz (normálértékekhez) viszonyítjuk. 6. Az orvoslás mérnöki típusú tevékenység (Seedhouse 2001). Ez a modell a biológiai tudományok eredményeit véli meghatározónak, e terület zavarainak korrekcióját célozza, azaz azt a felfogást, hogy az adott egyén akkor rendelkezik egészséggel, ha szervei (teste) jól müködnek, abban zavar nem mutatkozik. A pszichológiai jelenségek mögött is elsősorban a biológiai (testi) összetevők szerepét vizsgálja. Vannak azonban olyan egészségi állapotot befolyásoló zavarok (pl. pszichiátriai elváltozások), amelyek erősen függenek a kulturális, társadalmi, de még a gazdasági hatásoktól is, amelyek döntően egyfajta komplex miliőben fordulnak elő és megjelenésük és egészségi állapot befolyásolásuk nehezen magyarázható csupán a testi tünetek jelenlétével. A gyakorlat szempontjából igen fontos, hogy ez a modell betegség-centrikus és hibaorientált, kevéssé képes figyelembe venni az egyén vagy környezete eröforrásait, azokat a sajátosságokat, amelyek felhasználhatók a pozitív irányú változás előmozdításában és egy erőforrás tartalék képzésében. A mai szemlélet viszont éppen arra törekszik, hogy a pozitívumok kapjanak nagyobb szerepet a betegségek megelőzésében és kezelésében.

\section{Az egészség bio-pszicho-szociális (funkcionális) modellje}

A biomedikális modell túlhaladása olyan paradigmaváltást jelentett az orvoslásban, amely a bio-pszicho-szociális, azaz a holisztikus szemlélet meghonosodását jelentette. A bio-pszicho-szociális orvoslás fogalma George L. Engel amerikai pszichiáter nevéhez füződik, aki 1977-ben alkotta meg téziseit, szembe menve az akkor uralkodó biomedikális nézetekkel. Azaz a természettudományos meghatározottságot a lelki jelenségek vizsgálatával, valamint a társadalmi szempontok bevonásával egészítette ki, létrehozva egy holisztikus szemléletet. Az egészség, a betegség és a fogyatékosság ennek következ- 
tében az egyes hierarchikus szinteken lévő rendszerek viszonylagos épsége és funkcionalitása mentén kerül meghatározásra (Engel 1977). (3. sz. ábra)

3. számú ábra: Az egészség és betegség bio-pszicho-szociális modellje (George L. Engel, 1977., 1980.)
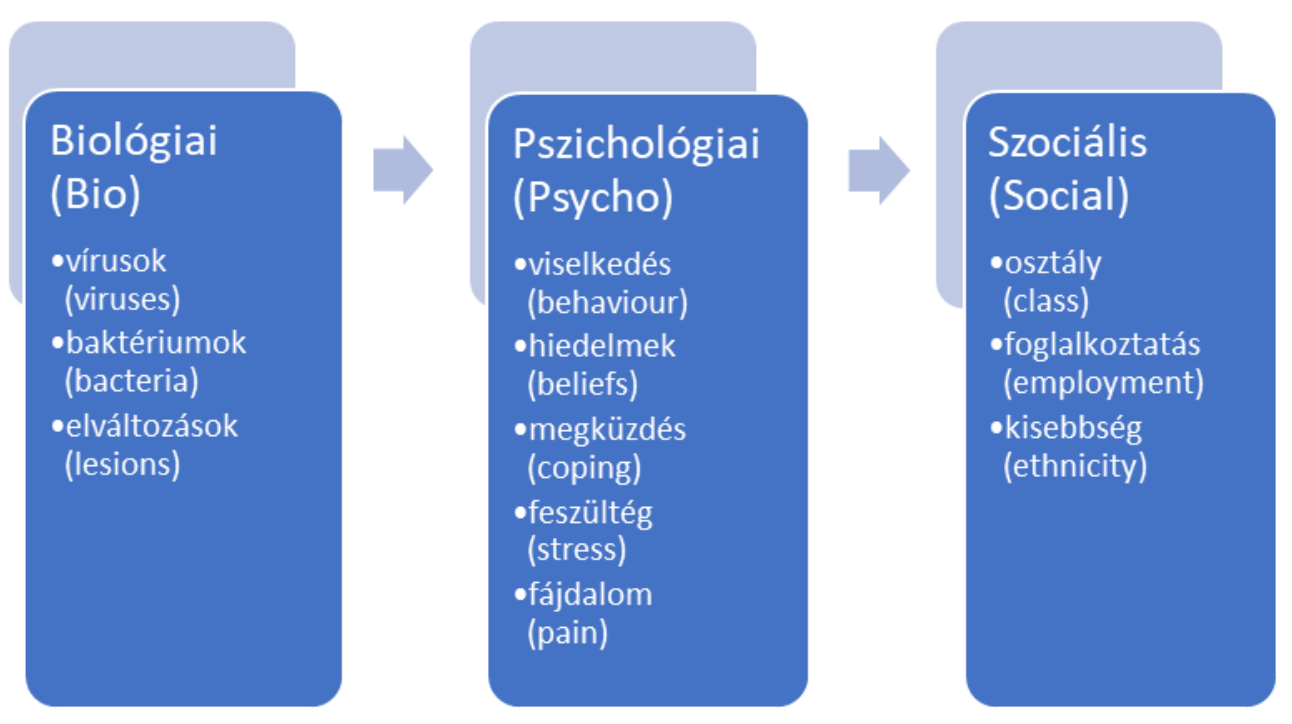

Forrás: (Saját szerkesztés)

- Biológiai (BIO): Alapvető felfogása az evidence based medicine (EBM) használata, azaz a tényeken alapuló orvoslás szemlélete. A szakmai felkészültség elsődleges feltétele, hogy a már ismert tudományos tényeknek megfelelően kezeljük az adott egyént. A tudományos tények alatt olyan kidolgozott protokollrendszerből álló gyógyítási folyamatot értünk, amely megfelelő tudományos bizonyítékok alátámasztásával, az eredmények tényszerü (evidencia) kritikus szemléletével és kiértékelésével készülnek, majd ezen evidenciák összesítését következtetés levonását (feedback) is magában foglalja. Ezen ismereteknek birtokában dől el a lehetséges diagnózis felállítása, valamint az, hogy mi a legmegfelelőbb kezelés az egyén számára betegségre irányultan. Ez adja az alapját, az orvosi munkának. A bio- az egyén testi elváltozásaival (a betegséggel) és annak gyógyításával foglalkozik, azt véve alapul, hogy ha valamelyik szerv megbetegszik, annak meggyógyításával az egyén egészsége helyreáll (Kőmüves 2017). 
- Pszichologiai (PSYCHO): A betegségek szempontjából az elsődleges az EBM szerinti gondolkodás, de ez önmagában nem elég. Engel felismerte azt a hiányt a biomedikális felfogásban, amit önmagában a biomedikális orvoslás nem tud kielégíteni. Napjainkban a gyakorlat több esetben sajnos még mindig azt mutatja, hogy nem követjük azt az egyébként gyógyításban előbbre mutató szemléletet, mégpedig, hogy ne a betegséget, hanem a beteget kezeljük. Tovább gondolva, a tökéletes cél az lenne a felfogás szerint, hogy ne beteget gyógyítsunk és kezeljünk, hanem az embert. Ennek a gondolkodásmódnak a vezérfonala, hogy az egyén nem csak a testi elváltozások által veszítheti el az egészségét, hiszen számos a lelki jóllétet befolyásoló tényezők miatt is sorra kerülhet ez a kedvezőtlen egészségi állapot még akkor is, ha a nyugati orvoslás szerint kimutathatóan semmilyen testi elváltozás nem igazolható az egyénnél. Engel ezen modell megalkotásakor azt kívánta sugallni, hogy az adott egyén egészségét nem csupán a testi jóllét, de a lelki is meghatározza. A betegségek kezelése kapcsán tehát erre komplex módon kell reagálni és ezt a modern orvoslási szemléletbe is be kell építeni, elrugaszkodva a korábbi évtizedekben követett biomedikális modell szemlélettől (Kőmüves 2017).

- Szociális (SOCIAL): Ha már említést nyert a modellben a testi és a lelki egészség Engel modellje azt is kiemeli és tartalmazza ebben a hármas pillérben, hogy az egyén egészségi állapotát a szociális, kulturális, társadalmi háttere is alapvetően meghatározza. Itt egyértelmüen az egyént mindenképp szükséges vizsgálni, hiszen a környezetétől nem választható el (Kömüves 2017).

Összességében és egyszerüen fogalmazva, ez egy egyén központú modell, amely figyelembe veszi a személyt, az egészségi problémáját, melyet az adott személy társadalmi kontextusában vizsgál. A biológiai: a fizikai egészségi állapotra utal. A pszichológiai: elismeri, hogy a személyes/pszichológiai tényezők is befolyásolják működését. A társadalmi: felismeri a társadalmi környezet fontosságát, a működésre nehezedő nyomást és korlátokat.

A bio-pszicho-szociális modell képezi az Alapját az Egészségügyi Világszervezet Müködésének, Fogyatékosság és Egészség Nemzetközi Osztályozásának (továbbiakban: FNO-ICF), amelyet ma már széles körben elfogadnak a fogyatékosság és a rehabilitáció keretéül (Waddell 2006). 
Az egészség társadalmi-gazdasági-kulturális-környezeti modellje

A XIX. századtól elfogadottá vált az az álláspont, hogy mely tényezők, határozzák meg az össztársadalmi egészséget. Egy évszázaddal később megjelent az egészségi állapotot meghatározó ,,szivárvány” modell ('Rainbow' model of the determinants of health), Dahlgren és Whitehead alkotta meg (Dahlgren és Whitehead 1991, 2006). A modell rávilágított arra a XX. század végén, hogy az egészségi állapot kialakulásának addig kevésbé előtérbe kerülő társadalmi-gazdasági-környezeti-kulturális egyéni meghatározó tényezőinek mekkora jelentősége van az egészség kimenetelében. Hangsúlyozta, hogy a társadalmi-gazdasági szempontrendszer részletes ismerete és vizsgálata is szükséges az egyéni és társadalmi egészség megítélésében.

A 4. sz. ábra az egészség fő meghatározóit mutatja be, mint befolyásrétegeket, egymás felett. Középpontba helyezve az egyént, annak betöltött életkorával, nemi jellegével és szervi (testi) tényezőivel, mint a genetikai állománya, és amelyek mindent kizárható kétség nélkül befolyásolják egészségi potenciálját, de nehezen befolyásolhatóak az egyén által. Az adott egyént körülvevő befolyásrétegek, azok, amelyek teljes egészében függenek az egyén ráhatásától. Ide tartozik mindazon befolyás, melyet összefoglaló névvel életmódnak fogalmaztak meg a szerzők. A legelső réteg az egyének által alkalmazott személyes viselkedés és életmód, amely olyan tényezőket tartalmaz, mint a dohányzási szokások és a fizikai aktivitás megléte vagy hiánya, egészséges táplálkozási irányelvek követési magatartása, alvási szokásai stb. $\mathrm{Az}$ egyének nem léteznek azonban légüres (egyedüli) térben, hiszen folyamatos és kölcsönös kapcsolatba lépnek barátaikkal, rokonaikkal és közvetlen közösségükkel, és a következő rétegben képviselt társadalmi és közösségi hatások alá kerülnek. Minél szélesebb kör következik, melyek az egyén egészségi állapotára bizonyítottan hatást gyakorolnak, ezek többsége az egyén egészsége fenntartásához szolgálnak segítségül (egészségmegőrző hatással bírnak). A harmadik rétegben ábrázolt tágabb hatások: az élet- és munkakörülményeket, az élelmiszer-ellátást, valamint a legfontosabb javakhoz és szolgáltatásokhoz való hozzáférés. Összességében a társadalom egészét jellemző gazdasági, kulturális és környezeti feltételek tartoznak bele az ábrán jelzett legkülső rétegbe (Ádány 2011). (4. sz. ábra). 
4. számú ábra: Az egészség fő meghatározói (Dahlgren és Whitehead modell, 1991.)

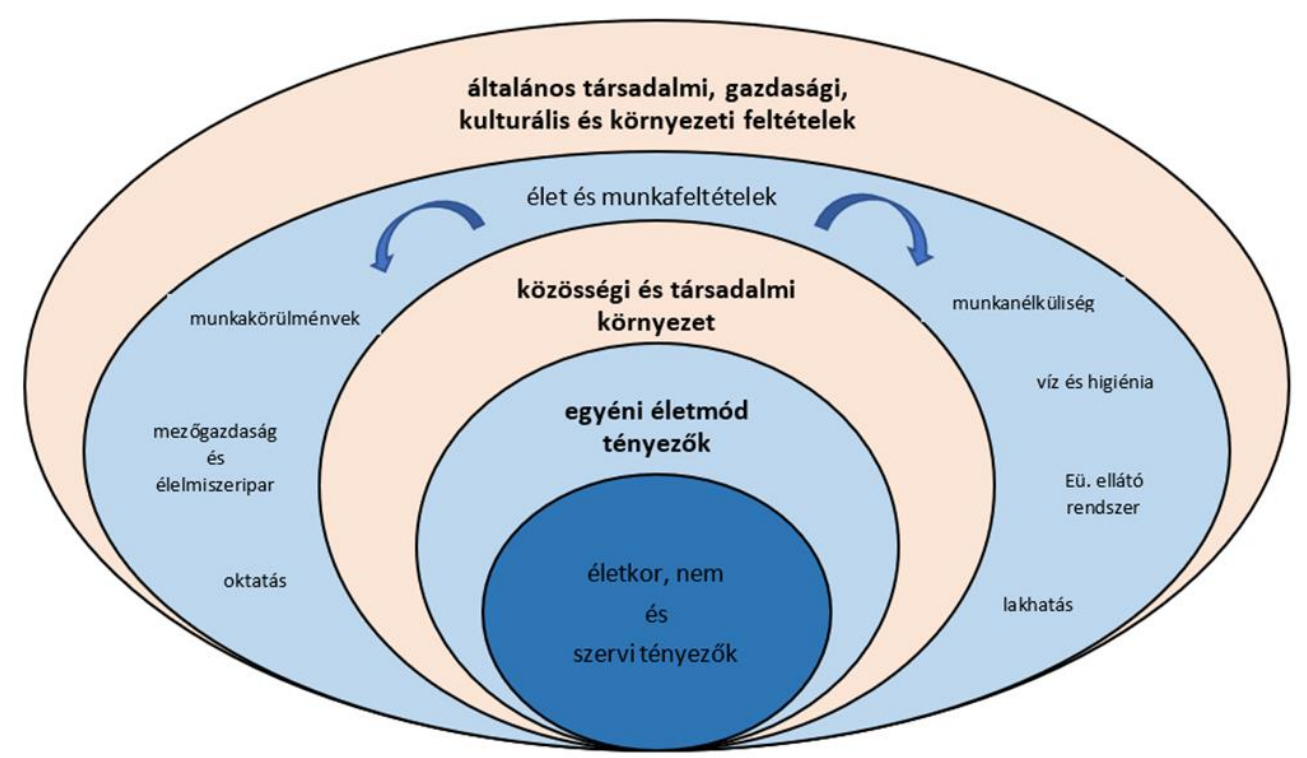

Forrás: (Saját szerkesztés)

A társadalmi, politikai, gazdasági és kulturális tényezők és az egészségi állapot közötti kapcsolat számos tanulmány tárgyát képezte az elmúlt időszakban. A fent részletezett modell fontossága és a benne szereplő állítások ma már evidenciaként értelmezhetők. Ennek felismerése és empirikus bizonyítása azonban meglehetősen újnak nevezhető. A tágabb, felsőbb szintü egészségmeghatározók hatásának a társadalmi egyenlőtlenségek leképződésének vizsgálata több esetben elmarad. A probléma feltérképezése és a beavatkozások értékelése általában csak a meghatározott alsóbb szinteken történő determinánsok hatására vonatkozik. Ezért fokozott erőfeszítéseket kell tenni annak érdekében, hogy bármikor lehetséges legyen azonosítani és számszerüsíteni, a különböző nemzetgazdasági növekedést segítő stratégiák jövedelemre gyakorolt hatásait, elsősorban az egyenlőtlenséget elszenvedett alacsony társadalmi-gazdasági csoportokban, és ezen csoportok egészségi állapotára gyakorolt hosszútávú hatásait is vizsgálni érdemes (WHO 2008, Terje és mtsi 2016). 
Az egészség társadalmi modellje-egészségegyenlötlenség

A társadalmi tényezők és az adott egyén társadalomban elfoglalt helye bizonyítottan alakítja az adott egyén egészségét. A legfontosabb tudományos dokumentum ezzel összefüggésben az 1980-ban megjelent Black Report (1980) volt, amit Peter Townsend és Nick Davidson készített. A kutatási jelentés részletesen beszámol arról, hogy a társadalmi egyenlőtlenségek, a társadalomban betöltött különböző pozíciók eltérő módon határozzák meg az individuum egészségi státuszát. Minél alacsonyabb presztízzsel rendelkező társadalmi réteget vizsgáltak, annál rosszabb egészségi állapotú egyénekkel találkoztak. A betegségek elöfordulásának gyakorisága csökkent és a betegségstruktúra is megváltozott, amikor magasabb jövedelemmel és vagyonnal rendelkező csoportokat elemeztek. Az egészségi állapot egyik meghatározó determinánsai között szerepel a társadalmi faktor és a társadalomban betöltött szerepe és annak körülményei (Townsend és Davidson 1982).

$\mathrm{Az}$ egészségre ható társadalmi tényezők jelentőségét felismerve, az Egészségügyi Világszervezet 2005-ben bizottságot hozott létre (Commission on the Social Determinants of Health, továbbiakban: CSDH) azzal a feladattal, hogy az egészségi egyenlőtlenségek csökkentésére javaslatokat tegyen. A bizottság zárójelentését 2008. évben hozták nyilvánosságra a CSDH munkájának elvi alapját képező modellel együtt (WHO 2008). (5. sz. ábra). Ismert ugyanis, hogy a társadalmi rétegződés arányaiban is meghatározza a társadalmi osztályhoz tartozók egészségi állapotát, így a társadalmi osztályhoz tartozó egyének egészégét is. Azokban az országokban, ahol a legalacsonyabb az egy före jutó nemzeti jövedelem, ott a legalacsonyabb az ország lakosságának születéskor várható átlagos élettartama, illetve a legmagasabb a csecsemőhalálozás mely mutatók egy ország lakosságának egészségéről szolgáltatnak információkat. Pusztán e két globális mutatót tekintve is egyértelmü, hogy azok az országok, ahol a szegénység általános, komoly egészségi állapotbéli okozatokkal is meg kell küzdeni és mely alapvetően terheli az adott ország egészségügyi ellátórendszerét az alapellátástól a szakellátáson át a kórházi ellátásig egyaránt. Hiszen a rossz szociális helyzet következménye, hogy problémák lehetnek az életmódtényezőkkel: a táplálkozással, a zavartalan pihenéssel és a személyi higiéné biztosításával is. Azokban az országokban, ahol az évszakok között előfordul a hideg tél (egészséget meghatározó környezeti tényezö), még fütési és öltözködési problémák is csökkentik a hátrányos szociális helyzetű közösségek betegségekkel szembeni ellenálló 
képességét, így nő a fertőző megbetegedések incidenciája, gyakoribbak és súlyosabbak a járványok előfordulása hozzájárulva más társadalmi egészségi állapotot tükröző mutatók (mortalitás, morbiditás) kedvezőtlen alakulásához.

A kidolgozott modell alapján a Bizottság megvizsgálta az egyenlötlenség csökkenéséhez vezető beavatkozási lehetőségeket, és összegyüjtötte az azokra vonatkozó tapasztalatokat, az un. ,jó gyakorlatokat”. Az ezek alapján készített, a kormányok számára szánt ajánlásait a WHO 2008 őszén tette közzé (WHO 2008).

Az 5. sz. ábra szemlélteti az egészség és az egészségegyenlötlenségre ható WHO-CCSDH által kidolgozott komplex modellt, melynek magyar nyelvü elkészítése Vitrai J. munkája. Az ábra szemlélteti, hogy a befolyásoló tényezők két csoportra osztottak strukturális és köztes egészség meghatározókra. A strukturális blokk részét képezi a társadalmi-, gazdasági-, politikai környezet, valamint az egyén társadalmi-gazdasági helyzete, mely társadalmi kohéziót és tőkét képez a köztes egészségmeghatározók között. A köztes befolyásolók része az egyén anyagi helyzete, magatartási és biológiai és pszichológiai tényezői. Egyéntől függetlenül, de szerepel a modellben az egészségügy is, mint köztes determináns az egészségre és az egészségegyenlőtlenség közvetlen befolyásoló tényezőjeként. A modell jól szemlélteti, hogy a meghatározók között szoros és közvetlen kapcsolat áll fent. (5. sz. ábra) 
5. számú ábra: Az egészséget meghatározó strukturális és köztes tényezők és kölcsönhatásaik (Solar és Irwin 2007., WHO- CSDH 2008.)

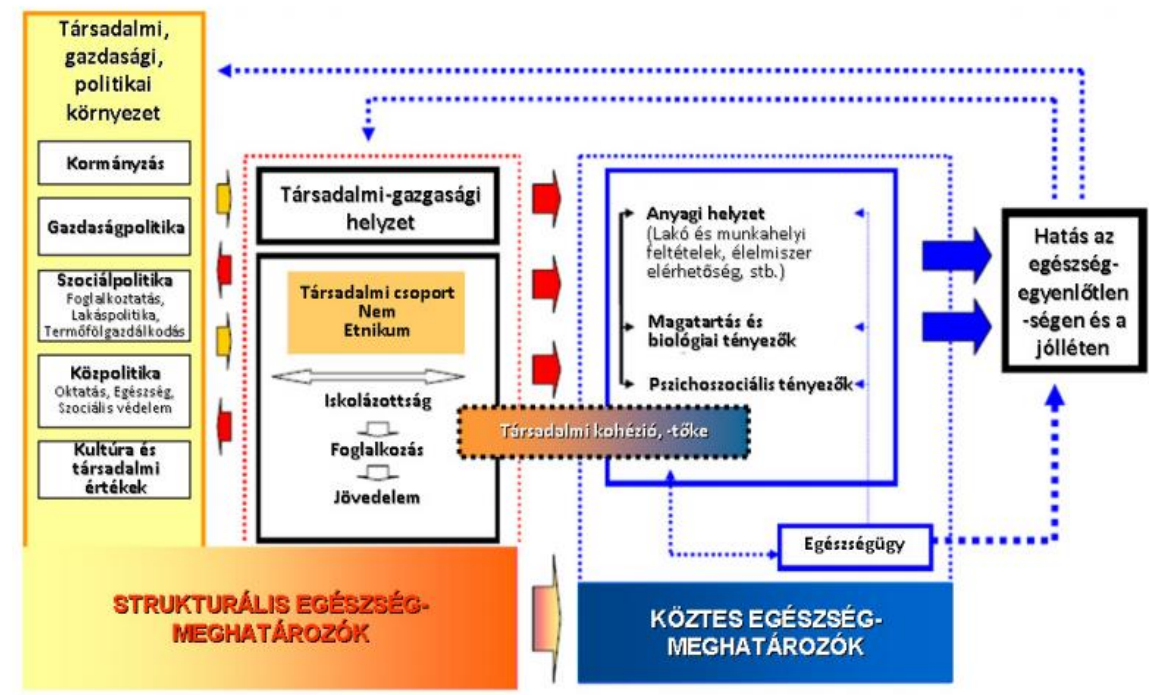

Forrás: dr. Vitrai József: Az egészség és az egészség-egyenlötlenségek egyéni és közösségi szintü befolyásoló tényezői-doktori értekezés, 2011. 17. oldal (magyar nyelvü ábra)

MEIKIRCH modell-az egészség és a jóllét összefüggésének dinamikus modellje

A Meikirch modell szerint az egészség a jóllét állapota, amely az egyéni képességek, az életút során keletkező kihívások, valamint a társadalmi és környezeti befolyásoló tényezők közötti kölcsönhatások eredménye (Bricher és Kuruvilla 2014, Bircher és Hahn 2016). A modell szerint egészségről akkor beszélhetünk, ha az egyén képességei, a társadalmi és környezeti tényezők egyensúlyba kerülnek az életút során keletkező kihívásokkal. Ezek a kihívások lehetnek élettani, pszichoszociális, vagy környezeti vonatkozásúak; az egyén helyzetétől és a körülményektöl függenek, de minden esetben az egyensúly megbomlása az egészség megromlásához vezet. A 6. sz. ábra grafikusan ábrázolja a modellt, amely szerint az egészség alkotóelemei a következők: 1. a személyes meghatározó tényezők, amelyek magukba foglalják az élet folyamán jelentkező szükségleteket és kihívásokat; az egyén biológiai potenciálját, amelyek az előbb említett kihívásokra adott válaszok; 2. az egészség társadalmi meghatározó tényezői; 3. a környezeti meghatározók. Ezek a tényezők egymással kölcsönhatásban vannak, befolyásolhatják a kihí- 
vásokra adott megfelelő válaszokat és a potenciálokat. A korábbi hasonló elméleti modellekkel ellentétben a Meikirich modell arra is rávilágít, hogy az egymáshoz szorosan kapcsolódó rétegek közötti hatás nem csak a közvetlenül mellette lévő rétegre, de mindegyikre kihatással és ráhatással van és a hatás oda-vissza értendő (Csizmadia 2018).

6. számú ábra: MEIKIRCH modell grafikus ábrázolása

(Bircher és Hahn 2016.)

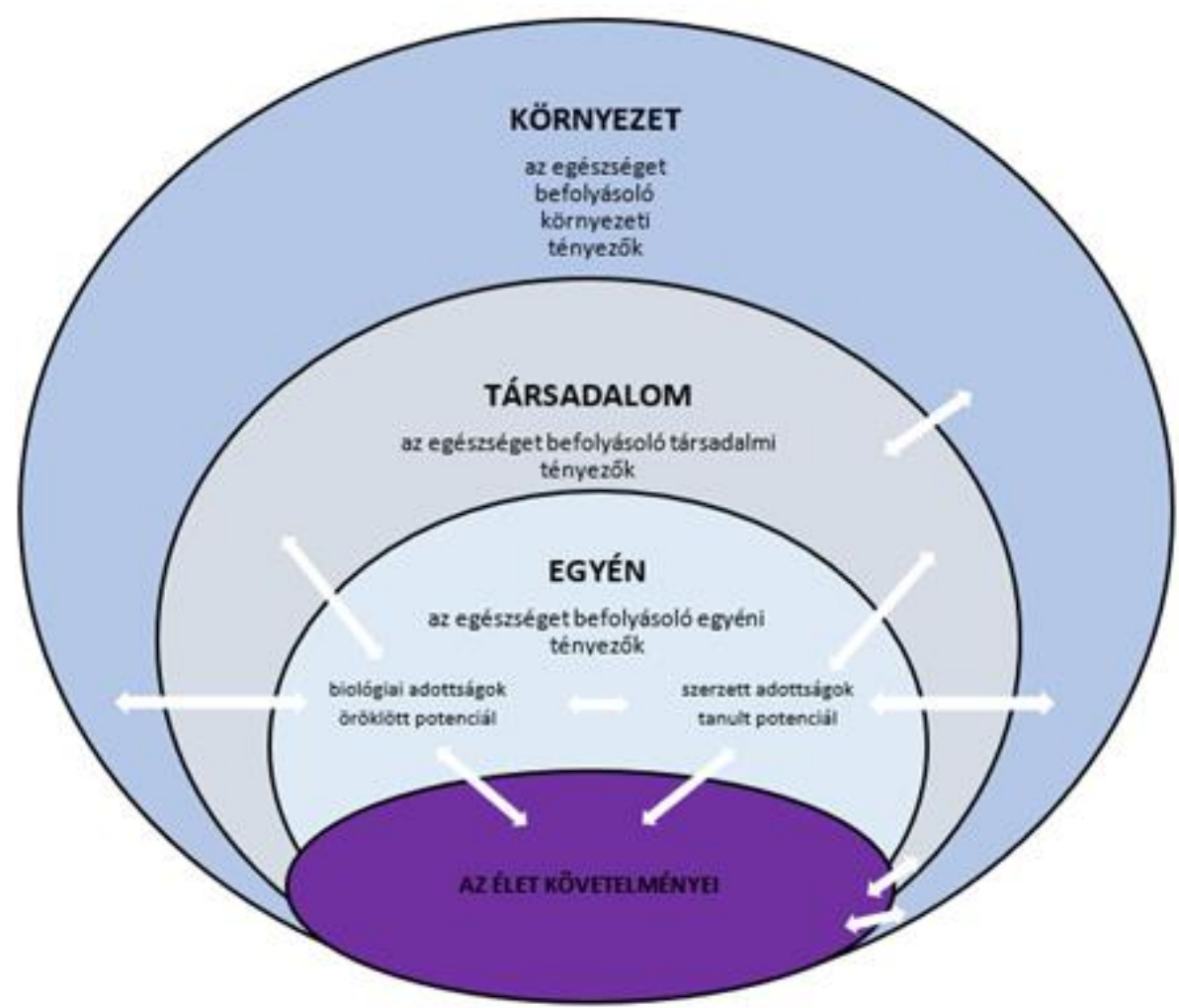

Forrás: (Saját szerkesztés)

\section{Összegzés}

Az egészségi állapot és ehhez kapcsolódóan az egészségügyi egyenlőtlenségek társadalomtudományi aspektusok szerinti vizsgálatának előzményei az 1980-as évek elejéig nyúlnak vissza. Több hazai vizsgálati eredmény látott napvilágot ebben a témakörben, mégis azt mondhatjuk, hogy elmúlt negyven évre vetítve ezeknek a kutatásoknak számát tekintve, inkább lemaradás tapasztalható (Orosz és Kollányi 2016). Ez is megerősíti azon meglátásunkat, 
mely szerint igen időszerüek, és össztársadalmi szinten is fontosak, azok a társadalomtudományi kutatások, melyek az egészségi állapotot meghatározó háttértényezők komplex szemléletét alkalmazva tárják fel az egészségi állapot jellemzőit, az egészségegyenlőtlenségek legfontosabb indikátorait. Az egészségben eltöltött életévek számát vizsgálva, a születéskor várható átlagos élettartam mutatóval ellentétben már nem látunk egyértelmü pozitív irányú javulást. Az életmóddal összefüggő kockázati tényezők felelnek a halálozások feléért Magyarországon. Négy felnőttből több mint egy dohányzott napi szinten 2014-ben - ez a harmadik legmagasabb arány az EU-ban. A felnőttkori elhízás is a legmagasabbak között van az EU egészéhez viszonyítva: 2017-ben öt felnőttből egy volt elhízott, ez az arány pedig folyamatosan növekedett az elmúlt évtizedben. A túlsúly és az elhízás a gyermekek körében is növekvő probléma, amely majdnem minden ötödik 15 évest érintett 2013 2014-ben (OECD 2019). Az egyének jólétét meghatározó várható egészséges élettartam emelkedése az egészségegyenlötlenségek csökkentésével érhető el, éppen ezért szükségesek azok az egészségszociológiai vizsgálatok, melyek a strukturális tényezőket, az egészségre közvetlenül ható magatartást és az egészségügyi ellátórendszerhez való hozzáférést a tanulmányunkban bemutatott modellek ötvözésével képesek vizsgálni. Az ilyen módon nyert eredményekre reflektáló beavatkozások tervezése és megvalósítása, az egyenlőtlenségek csökkentése és az egészségben eltöltött életévek emelkedése mellett a társadalom és a gazdaság hosszú távú fejlődését szolgálhatják. 


\section{Felhasznált irodalom}

1. Állami Egészségügyi Ellátó Központ (ÁEEK) (2021): Egészségtudományi fogalomtár. Letöltés helye:

https://fogalomtar.aeek.hu/index.php/Eg\%C3\%A9szs\%C3\%A9gfejleszt \%C3\%A9s, Letöltés ideje: 2021.03.17.

2. Ádány R. (szerk. 2011): Megelőző orvostan és népegészségtan. Budapest, Medicina Könyvkiadó Zrt.

3. Bircher J. Hahn EG (2016). Understanding the nature of health: New perspectives for medicine and public health. Improved wellbeing at lower costs [version 1]. F1000 Research, 5. 167. 2016 Feb 12 (5):167. doi: 10.12688/f1000research.7849.1.

4. Bircher J., Kuruvilla S. (2014): Defining health by addressing individual, social, and environmental determinants: New opportunities for health care and public health. Journal of Public Health Policy, 35 (3) 363-386.

5. Borbás, I., Gődény, S., Juhász, J., Kincses, Gy., Mihalicza, P., Pékli, M. \& Varga, E. (2008): Egészségtudományi fogalomtár. Gyógyszerészeti és Egészségügyi Minőség- és Szervezetfejlesztési Intézet Informatikai és Rendszerelemzési Főigazgatóság.

6. Csizmadia P. (2018): Kísérlet az egészség fogalmának újradefiniálására. A Meikirch modell. Egészségfejlesztés, 59. (1): 45-51. DOI: http://dx.doi.org/10.24365/ef.v59i1.239

7. Dahlgren, G., Whitehead, M. (1991). Policies and Strategiesto Promote Social Equity in Health. Stockholm: Institute for Futures Studies

8. Dahlgren G., Whitehead M. (2006): European strategies for tackling social inequities in health - levelling up part 2 (WHO report, PDF)

Letöltés helye:

https://www.euro.who.int/_data/assets/pdf_file/0018/103824/E89384.pdf Letöltés ideje: 2021.03.17.

9. Engel, G. L. (1977): The Need for a New Medical Model: A Challenge for Biomedicine. Science, 196(4286): 129-136.

10. EUROSTAT-European Commission (2017): European Union Statistics on Income and Living Conditions (EU-SILC). Letöltés helye:

https://ec.europa.eu/eurostat/web/income-and-living-

conditions/data/database, Letöltés ideje: 2021.03.17. 
11. Mc Ginnis JM, Williams-Russo P, Knickman JR (2002). The case for more active policy attention to health promotion. Health Aff (Millwood) 21(2):78-93.

12. Moravcsik-Kornyicki, Á., Kósa, Z., Gyulai, A., Jávorné Erdei, R., Kósa, K. (2017): Területi egyenlőtlenségek hosszú idősoros elemzése a várandós nők egészségi állapotát vizsgálva. Orvosi Hetilap. 158 (29), 1131-1142.

13. Kapitány, Á., Kapitány, G. (2014): Egészség-betegség, mint szimbolikus társadalmi konstrukció. In Kapitány, Á., Kapitány, G. (szerk.): A mindennapi élet jelrendszereiről. Szocio-szemiotikai tanulmányok. Budapest, Loisir Könyvkiadó (pp. 507-525.).

14. Kömüves S. (2017): Az engeli biopszichoszociális modell. METSZETEK 6 (2): 98-123. DOI 10.18392/metsz/2017/3/10

15. KSH (2021): 6.1.7. Születéskor várható átlagos élettartam, átlagéletkor (2001-). Letöltés helye:

https://www.ksh.hu/docs/hun/xstadat/xstadat_eves/i_wdsd008.html Letöltés ideje: 2021.05.17.

16. Lalonde, M. (1981): A new perspective on the health of Canadians, a working dokument. Government of Canada.

Letöltés helye: http://www.phac-aspc.gc.ca/ph-sp/pdf/perspect-eng.pdf Letöltés ideje: 2021.03.17.

17. Libicki É., R., Fedor A. (2020): A szubjektív egészségi állapot kutatási hátterének többszintű megközelítése a társadalmi egyenlőtlenségek tükrében. ACTA MEDICINAE ET SOCIOLOGICA 11 : 31 pp. 13-25., 13 p.

18. McGinnis JM, Williams-Russo P, Knickman JR. (2002): The case for more active policy attention to health promotion. Health Aff (Millwood). 21(2):78-93.

19. OECD (European Centre for Disease Prevention and Control (2021): State of Health in the EU · Magyarország · Egészségügyi országprofil 2019.

Letöltés helye:

https://ec.europa.eu/health/sites/default/files/state/docs/2019_chp_hu_hu ngary.pdf, Letöltés ideje: 2021.05.17.

20. Orosz É., Kollányi Zs. (2016): Egészségi állapot, egészségegyenlötlenségek nemzetközi összehasonlításban. In: In: Kolosi, Tamás; 
Tóth, István György (szerk.) Társadalmi Riport. Budapest, Magyarország: TÁRKI (2016) 444 p. pp. 332-355.

21. Parson T. (1948): Definitions of Health and Illness in the Light of American Values and Social Structure. (2rid Ed.). New York, Free Press of Glencoe.

22. R. Fedor Anita (2019): A szubjektív egészségi állapot egészségszociológiai aspektusai. EGÉSZSÉGFEJLESZTÉS 60 : 5 pp. 99-110., 12 p. (2019)

23. Seedhouse D., Cribb A. (1989): Changing Ideas in Health Care. Alan Cribb Wiley., 21.June 1989.

24. Seedhouse D. (2001): Health: The Foundations for Achievement, 2nd Edition, ISBN: 978-0-471-49011-1

25. Stokes, J., Noren, J., Shindell, S. (1982): Definition of terms and concepts applicable to clinical preventive medicine. J Community Health 8, 33-41. https://doi.org/10.1007/BF01324395.

26. Székely, L., Simon, T., Vergeer, F. (2007): Az „egészség” fogalmának újraértelmezése I. Egészségfejlesztés, 48, (4-6), 37-47.

27. Inequalities Survey of the General Population: The European Social Survey Rotating Module on the Social Determinants of Health

28. Terje A Eikemo, Clare Bambra, Tim Huijts, Rory Fitzgerald(2016). The First Pan-European Sociological Health Inequalities Survey of the General Population: The European Social Survey Rotating Module on the Social Determinants of Health. European Sociological Review 33(1): jcw019

29. Townsend P., Davidson N. (1982): Inequalities in Health: the Black Report, Penguin, London.

30. Vitrai J., Mihalicza P. (2006): „Egészségi állapot”: in: Társadalmi riport 2006, Kolosi Tamás, Tóth István György, Vukovich György (szerk.). Budapest: TÁRKI, p. 138-150.

31. Waddell G. (2006): Preventing incapacity in people with musculoskeletal disorders. British Medical Bulletin; 77 and 78: 55-69. DOI: 10.1093/bmb/ldl008 
32. World Health Organization (WHO) (2006): Constitution of the world health organization. Basic Documents, Forty-fifth edition, Supplement, October 2006.

Letöltés helye:

https://www.who.int/governance/eb/who_constitution_en.pdf

Letöltés ideje: 2021.03.17.

33. World Health Organization WHO (2008): Closing the gap in a generation. Report of the Commission on Social Determinants of Health., 2008. Letöltés helye:

https://apps.who.int/iris/bitstream/handle/10665/43943/9789241563703_en g.pdf;jsessionid=BBD25D688D8665BC515160F56DEDE6D1? sequence=1 Letöltés ideje: 2021.03.17.

34. Wylie CM (1970): The definition and measurement of health and disease. Public Health Reports 85:100-104. 